\title{
Pengembangan Usaha Kecil Makanan pada Komunitas Perempuan di Kecamatan Tanjung Morawa Kota Deli Serdang
}

\author{
Ritha Fatimah Dalimunthe ${ }^{1)}$, Arlina Nurbaity Lubis ${ }^{2)}$ \\ ${ }^{1,2}$ Universitas Sumatera Utara \\ rithadalimunthe@gmail.com, arlina@usu.ac.id
}

\begin{abstract}
Abstrak
Komunitas perempuan UMKM Tanjung Morawa yang beranggotakan umumnya Ibu Rumah Tangga siap mengembangkan usaha berbasis usaha kecil makanan. Pelaksanaan kegiatan pengabdian pada komunitas tersebut berupaya memaksimalkan potensi komunitas melalui pemberdayaan dengan memberikan ipteks berwirausaha di komunitas tersebut. Serangkaian kegiatan pelatihan, pendampingan, serta sosialisasi dilakukan kepada mitra pengabdian dengan tujuan terciptanya kewirausahaan baru dengan memanfaatkan bisnis online serta bahan baku alami dan sehat. Bisnis model kanvas diperkenalkan kepada komunitas untuk meningkatkan daya saing berbasis ekonomi keluarga. Pada kegiatan pengabdian ini, ibu-ibu rumah tangga yang tergabung dalam komunitas dikembangkan menjadi women entrepreneur berkelompok dengan yang sebelumnya berjumlah 10 anggota menjadi 23 pelaku usaha di wilayah Tanjung Morawa, Kabupaten Deli Serdang, Sumatera Utara. Fokus pengembangan komunitas berbasis makan olahan dengan bahan baku juga memanfaatkan ketersediaan lahan yang non-produktif seperti penanaman bayam dan kangkung. Pemberdayaan komunitas ini menargetkan peningkatan jumlah wirausaha baru dalam kalangan komunitas yang akan membantu ekonomi keluarga sekaligus membuka lapangan kerja baru. Kegiatan pengabdian ini menargetkan pembentukan lima wirausaha baru yang akan didampingi secara khusus untuk pengembangan bisnis model kanvas.
\end{abstract}

Kata Kunci : kewirausahaan, komunitas perempuan, pengabdian, pengembangan usaha, usaha kecil

\section{PENDAHULUAN}

Pembangunan ekonomi sangat bergantung pada kualitas sumber daya manusia di suatu wilayah. Kualitas sumber daya manusia ini dapat selalu ditingkatkan melalui pelatihan dan pendampingan (Siahaan, 2015). Pemberdayaan masyarakat di suatu wilayah sendiri harus dimulai dari titik yang paling kecil, mulai dari individu yang membangun ekonomi keluarga dan kemudian ekonomi keluarga akan membangun ekonomi kelompok hingga nantinya meningkatkan ekonomi nasional secara agregat. Peningkatan sumber daya manusia yang berkualitas juga mampu meningkatkan kesejahteraan masyarakat di sekitarnya dengan membuka sejumlah lapangan pekerjaan. Entrepreneurship hadir sebagai jembatan yang menghubungkan kualitas sumber daya manusia, lapangan pekerjaan, dan peningkatan ekonomi masyarakat (Anton, Muzakan, \& Muhammad, 2015). Kondisi ini mendukung kemandirian masyarakat sehingga akan membantu angka pengangguran yang serta memicu penurunan angka kemiskinan.

Permasalahan utama pengangguran adalah ketidakseimbangan antara kebutuhan pasar tenaga kerja (dari sisi permintaan) dengan kualitas serta kuantitas tenaga kerja yang sesuai dengan kebutuhan pasar atau dari sisi penawaran tenaga kerja (Dervishi, 
2017). Ketidakseimbangan ini mengakibatkan banyak pasokan (supply) tenaga kerja yang tidak sesuai dengan kebutuhan dunia usaha dan industri saat ini (excess supply). Salah satu solusi dalam menyelesaikan permasalahan pada kondisi ini adalah dengan membuka lapangan kerja baru yang sesuai dengan pasokan tenaga kerja yang tersedia (Soylu, Çakmak, \& Okur, 2018). Masyarakat dibimbing agar tidak lagi terfokus pada posisi pencari pekerjaan melainkan sebagai pembuka lapangan pekerjaan. Pembukaan lapangan pekerjaan tidak harus selalu memerlukan kualitas SDM yang terbaik. Kebutuhan kualitas SDM dapat disesuaikan dengan aktivitas usaha yang akan dibuka. Selain itu, sumber daya manusia dapat dikembangkan. Seorang entrepreneur merupakan seseorang yang mengelola dan berani mengambil risiko serta dapat melihat peluang usaha baru (Anton et al., 2015). Disamping itu entrepreneurship mencerminkan sikap mental yang selalu aktif meningkatkan kegiatan dalam usaha yang muncul dari diri seseorang.

Sebagian besar wilayah Indonesia masih menganut sistem segretasi pekerjaan berdasarkan gender. Secara umum, masyarakat Indonesia menganggap laki-laki sebagai tulang punggung keluarga yang mencari nafkah untuk keluarga dan perempuan berperan sebagai ibu rumah tangga yang mengurus aktivitas rumah tangga. Kondisi ini memang sudah mulai bergeser dengan gencarnya emansipasi wanita di lingkungan kerja. Meskipun demikian, tingat masyarakat perempuan yang belum efektif secara ekonomi masih tergolong tinggi. Oleh karena itu, pemberdayaan perempuan selain berperan sebagai ibu rumah tangga juga diharapkan memiliki kemampuan untuk berwirausaha. Apabila pemberdayaan ini efektif, akan banyak wirausaha baru dari kalangan ibu-ibu rumah tangga dan menjadi aktif secara ekonomi. Oleh karena itu, kegiatan pengabdian masyarkat pada tahun ini difokuskan pada pemberdayaan ibu-ibu rumah tangga di tingat kelurahan.

Target dari kegiatan pengabdian ini adalah pemberdayaan ibu-ibu rumah tangga dan menciptakan women entrepreneur. Tim pengabdian mempersiapkan kegiatan pendampingan bagi ibu-ibu rumah tangga yang berminat menjadi wirausaha dan membentuk kelompok wirausaha di kelurahan tersebut. Arahan dari tim pengabdian dalam pengembangan wirausaha ditargetkan dalam bentuk usaha kecil yang bergerak dibidang kuliner (Yusr, Mokhtar, Salimon, \& Perumal, 2018). Pelaku usaha merupakan penjual makanan yang memiliki kontribusi bagi keluarga untuk meningkatkan pendapatan serta ekonomi di daerah Kabupaten Deli Serdang namun juga membuka pekerjaan baru dan mengurangi jumlah pengangguran. Sektor kuliner diangkat dengan mempertimbangkan keahlian ibuibu rumah tangga dalam mengolah makanan semberi mempertimbangkan kuliner sebagai sektor unggulan di Sumatera Utara. Sektor kuliner juga menjanjikan sebab sektor ini bergerak dalam lingkup kebutuhan pokok manusia, khususnya dari aspek pangan (Sadiku, Musa, \& Ashaolu, 2019).

Kegiatan pengabdian ini meliputi pengembangan pada tiga aspek utama, yaitu (1) aspek ekonomi, yang diharapkan akan adanya peningkatan pendapatan ekonomi keluarga setelah dilakukakan kegiatan pelatihan dan pendampingan tentang kewirausahaan; (2) aspek sosial budaya, yang membantu peningkatan tata nilai masyarakat dengan budaya bekerja keras dan tangguh dalam menjalankan usaha, selain itu pembentukan komunitas juga bermakna pada pengembangan budaya gotong-royong secara bersama-sama menyelesaikan permasalahan dan tugas-tugas komunitas; dan (3) aspek kesehatan, yang menekankan pada produksi usaha kuliner berbahan sehat, higienis serta legal.

Pelaksanaan focussed group discussion pada kelompok masyarakat sebagai pembuka kegiatan pengabdian menyimpulkan bahwa beberapa kendala yang dihadapi oleh masyarakat dalam peningkatan ekonominya meliputi, (1) dorongan kondisi ekonomi yang membuat masyarakat tergerak untuk membantu ekonomi keluarga sembari menyeimbangkan tugas rumah tangga; (2) beberapa ibu rumah tangga sudah memulai usaha namun terkendala aktivitas promosi, khususnya pada era digitalisasi; (3) legalitas usaha masih belum tercapai; (4) belum adanya kolaborasi antar masyarakat sehingga semua terasa lebih berat saat harus mengerjakan sendiri. 


\section{METODE}

Kegiatan pengabdian masyarakat kali ini dilakukan di daerah Bandar Labuhan Kecamatan Tanjung Morawa Kabupaten Deli Serdang yaitu bagi ibu rumah tangga yang berada di kelompok usaha kecil makanan pada komunitas perempuan. Komunitas ini bernama komunitas "UMKM WarnaWarni" yang beranggotakan perempuan di wilayah tersebut.

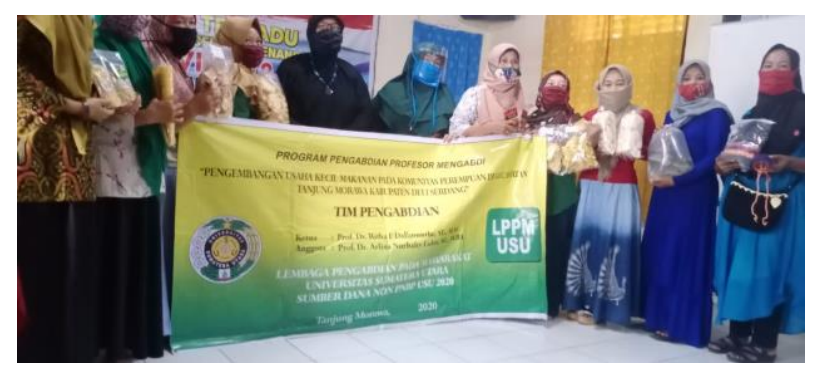

Gambar 1. Komunitas UMKM Warna-Warni

Kegiatan pengabdian masyarakat dilaksanakan dengan tiga tahapan utama. Pertama, tim pengabdian merekrut kembali masyarakat khususnya perempuan untuk bergabung dalam komunitas "UMKM Warna-Warni" sembari membentuk wirausaha baru berbasis kuliner dari komunitas tersebut. Pada kegiatan tersebut tim pengabdian melaksanakan focus group discussion bersama komunitas dan masyarakat. Tim pengabdian menyampaikan maksud dan tujuan pelaksanaan kegiatan pengabdian ini dan mendapatkan apreasiasi yang baik dari masyarakat dan pemerintah setempat. Pada kesempatan itu pula tim pengabdian membentuk whatsapp group (WAG) komunitas yang mendukung rangkaian kegiatan pengabdian bersama dengan komunitas sebagai mitra pengabdian.

Tahap kedua dari pelaksanaan kegiatan pengabdian ini adalah pelatihan serta workshop yang disebut dengan nama "wirausaha sukses" dengan rangkaian kegiatan (1) pelatihan kewirausahaan; (2) pelatihan business canvas model; (3) workshop penggunaan IT dan pemasaran digital yang saat ini sangat diperlukan melihat pergeseran preferensi belanja masyarakat (Lubis, 2018); dan (4) pelatihan pembuatan mie kreatif berbahan dasar daun kelor dan bayam. Pada tahapan ini tim pengabdian fokus pada transfer ipteks yang optimal kepada masyarakat dan komunitas UMKM Warna-Warni. Pelatihan perlu dilakukan sebagai bagian dari peningkatan kualitas sumber daya manusia masyarakat (AlHawary, 2015; Raheja, 2015).

Tahap ketiga dari pelaksanaan kegiatan pengabdian ini adalah kegiatan pendampingan serta pengempangan usaha dari komunitas mitra. Ketertarikan komunitas pada ekonomi kreatif berkembang dengan aktivitas wirausaha dengan membentuk usaha sejenis. Masyarakat memberdayakan lahan yang lama tidak terpakai sebagai sarana bercocok-tanam bahan baku pengolahan mie, seperti bayam. Pada pengolahan lahan, komunitas perempuan juga dibantu bapakbapak yang menjadi suami anggota komunitas tersebut. Pendampingan secara berkala dilakukan untuk membantu dari hulu (bahan baku), panen bahan baku, pengolahan menjadi mie, serta uji coba produk bersama dengan masyarakat. Antusiasme komunitas dan masyasrakat dirasakan sangat baik pada pelaksanaan kegaitan pengabdian ini.

Mitra secara khusus berkontribusi aktif pada rangkaian kegiatan yang telah dilaksanakan. Keterlibatan Rumah Inspirasi Ratu Salmah sebagai bagian dari fasilitator kegiatan juga sangat membantu dan menginspirasi komunitas dengan motivasi khususnya kesuksesan ekonomi kreatif yang telah dicapai.

\section{HASIL DAN PEMBAHASAN}

\section{Peserta Pengabdian}

Pengabdian ini melibatkan pengembangan kelompok mitra, yaitu komunitas "UMKM WarnaWarni" di wilayah Bandar Labuhan, Kecamatan Deli Serdang, Sumatera Utara. Pada pelaksanaan tahap satu kegiatan pengabdian ini, anggota komunitas tersebut meningkat, dari sebelumnya beranggotakan 10 orang menjadi 15 orang anggota. Pada tahapan ini, seluruh anggota sudah memulai usahanya di bidang kuliner. Pada pendampingan terakhir, komunitas ini sudah berkembang menjadi 23 orang yang tergabung dalam whatsapp group bersama.

Pendataan karakteristik anggota komunitas mitra yang mengikuti kegiatan pengabdian telah terdata sebanyak 15 orang anggota yang sebelumnya telah mengikuti pelatihan. Karakteristik ini 
dikelompokkan berdasarkan jenjang pendidikan, dirangkum dalam Gambar 2.

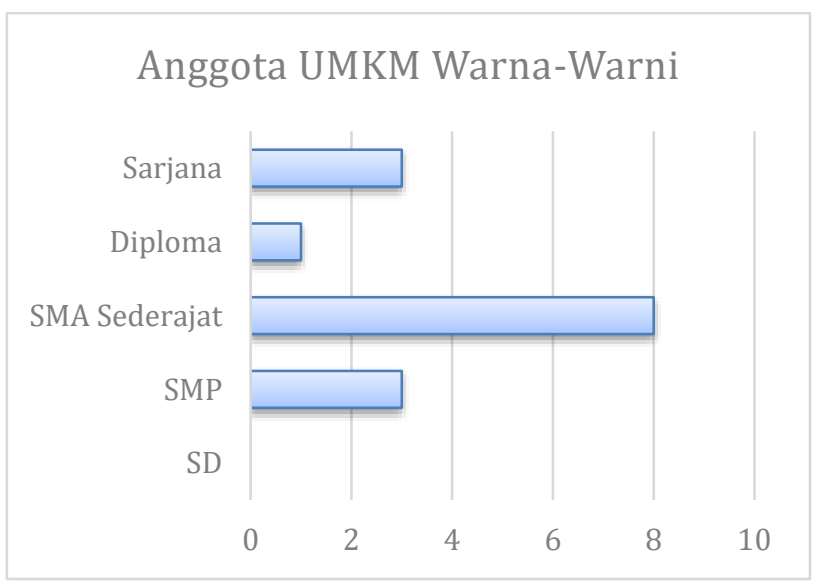

Gambar 2. Mitra Berdasarkan Pendidikan Terakhir

Gambar 2 menunjukkan bahwa mayoritas dari anggota UMKM Warna-Warni yang juga telah memulai usahanya di bidang kuliner memiliki jenjang pendidikan terakhir pada jenjang SMA atau sederajatnya. Pada kondisi saat ini, tuntutan keahlian dan pendidikan tenaga kerja memerlukan kualifikasi yang tinggi (Indonesian Statistics Bureau, 2017). Oleh karena itu, banyak dari mereka merasa sulit mendapatkan pekerjaan yang diharapkan, meskipun memang sebagian memilih fokus untuk menjaga peran sebagai ibu rumah tangga. Kewirausahaan membuat mereka merasa aktif kembali secara ekonomi dengan membantu ekonomi keluarga melalui berbagai aktifitas berwirausaha (Ogbechie, 2015).

Seluruh anggota komunitas ini adalah perempuan dan secara kebetulan semuanya adalah ibu rumah tangga yang harus berbagi peran antara mengurus rumah tangga dan mendukung kebutuhan ekonomi. Berwirausaha dirasakan sebagai pilihan yang sangat tepat untuk menyeimbangkan kedua pilihan tersebut. Fleksibilitas waktu dalam bekerja menjadi kunci dalam menyeimbangkan kedua peran sekaligus.

Dari sisi usia, dua dari lima belas anggota komunitas masih berusia 30 tahun ke bawah. Artinya komunitas ini memiliki dua orang wirausaha muda.
Selebihnya adalah ibu-ibu rumah tangga yang berusia sampai dengan 53 tahun.

\section{Hasil Pelaksanaan Kegiatan}

Tim pengabdian telah melakukan sosialisasi dan pendampingan terkait pendirian usaha berbasis makanan lokal, mulai dari pengembangan jiwa kewirausahaan, sampai dengan pengembangan usaha dan pengurusan legalitas usaha tersebut. Kegiatan pengabdian ini fokus pada pengenalan dan adaptasi model bisnis kanvas kepada para ibu-ibu rumah tangga. Pada kegiatan pengabdian ini, sosialisasi dan pelatihan dihadiri oleh 15 orang ibu rumah tangga yang sebagian sudah menjadi pelaku usaha berbasis makanan. Meskipun legalitas usaha masih belum semuanya terapai, antusiasme masyarakat dalam mengembangkan usahanya dan memperdalam bisnis model kanvas ini patut diacungkan jempol. Pada kegiatan pengabdian ini tim menargetkan penciptaan lima wirausaha baru berbasis bisnis model canvas tersebut. Pengabdian ini juga mengidentifikasi bahwa banyak dari pelaku usaha belum memiliki legalitas usaha. Sosialisasi dan pendampingan terkait pengurusan legalitas usaha telah dilaksanakan melalui pengabdian pada masyarakat di kalangan komunitas perempuan wilayah Tanjung Morawa, Kabupaten Deli Serdang, Sumatera Utara.

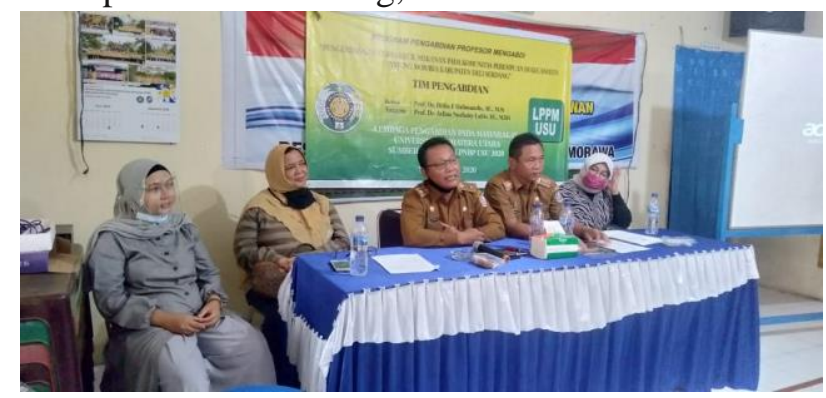

Gambar 3 Apresiasi Dinas pada Kegiatan Sosialisasi

Dalam upaya pengembangan daya saing pelaku usaha pada komunitas tersebut, tim pengabdian telah melakukan kerjasama dengan rumah inspirasi Ratu Salmah untuk membantu 
membina dan membimbing pelaku usaha yang menjadi komunitas wanita di daerah pengabdian kepada masyrakat. Dalam kesempatan ini pula tim pengabdian mengundang dinas setempat untuk mencoba hasil karya pelaku usaha setempat dengan memanen produk lokal sekaligus mengolahnya menjadi produk industri makanan ringan.

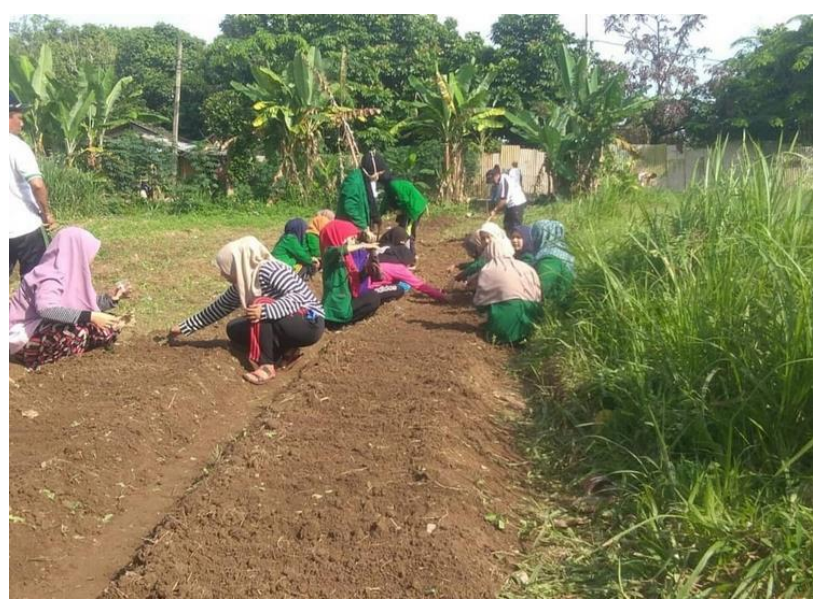

Gambar 4. Pengolahan Lahan Tak Terpakai

Serangkaian kegiatan pengabdian juga dilakukan untuk mengembangkan usaha kreatif berbasis makanan dengan menggunakan bahan alami dan sehat. Komunitas berinisiatif mengembangkan lahan yang tidak terpakai sebagai area pembibitan dan budidaya tanaman seperti bayam yang akan dijadikan sebagai bahan pelengkap dan pemberi warna pada produk mie. Penggunaan bayam sebagai pewarna alami dipercaya memberikan warna hijau yang menarik namun tetap sehat untuk dikonsumsi sembari memberikan rasa unik kepada mie tersebut. Pada tahapan ini telah tercapai perubahan tata nilai di masyarakat. Semangat gotong-royong membuat pekerjaan yang berat menjadi semakin ringan (Rolitia, Achdiani, \& Eridiana, 2016). Lahan yang tidak terpakai, akan terasa sangat berat jika dikerjakan sendirian. Pada kesempatan ini, kebersamaan komunitas UMKM Warna-Warni yang juga didukung oleh keluarga, khususnya suami anggota komunitas mampu mengolah lahan tidak terpakai menjadi lahan produktif dengan penanaman bahan baku. Pada aktivitas ini, daya saing produk olahan komunitas juga akan meningkat dengan adanya pasokan yang stabil dan sehat dari pengolahan lahan sendiri (Maqbool, Rafiq, Imran, Quadeer, \& Abbas, 2014).

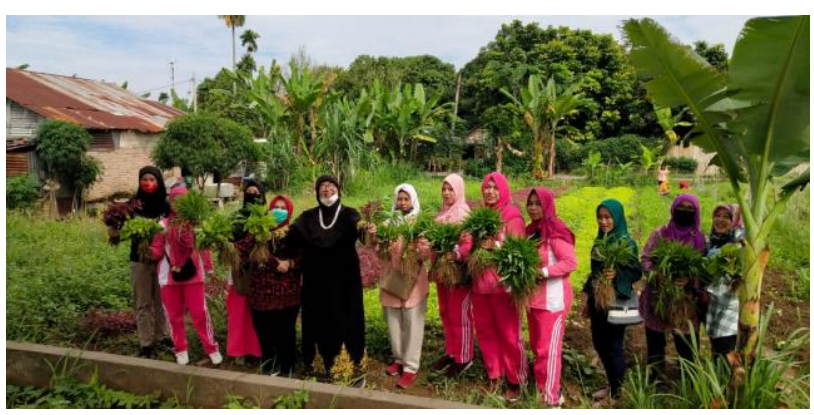

Gambar 5. Panen Bersama Komunitas

Pengolahan lahan yang sebelumnya dilakukan oleh komunitas telah berhasil memberikan hasil panen berupa bayam merah yang akan diolah menjadi mie merah dan bayam hijau, serta kangkung yang akan diolah menjadi mie hijau. Penanaman bahan baku ini dilakukan tanpa pestisida demi menjaga kualitas kesehatan dari bahan-bahan yang digunakan sebagai bahan baku (Gopalakrishnan, 2019). Tim pengabdian menekankan kepada mitra bahwa bahan baku yang sehat akan menghasilkan produk akhir yang sehat pula (Sigurdsson, Larsen, \& Gunnarsson, 2014). Hal ini sudah menjadi tren yang berkembang di masyarakat dengan pola hidup yang semakin ke arah pola hidup sehat.

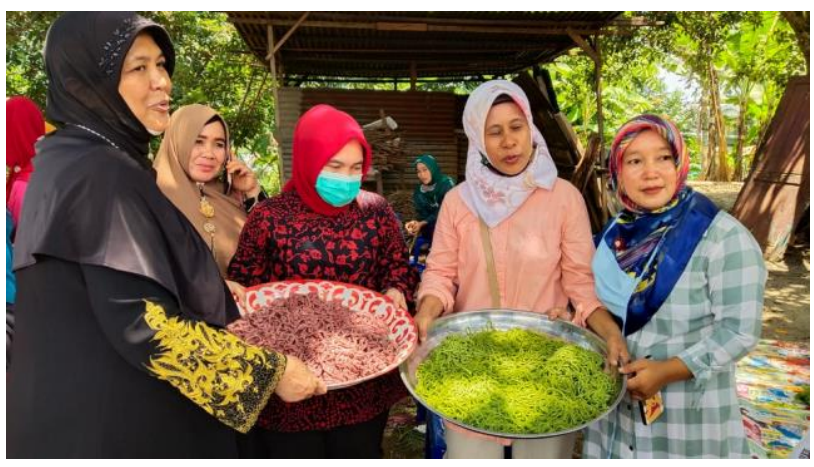

Gambar 6. Pengolahan Bahan Baku Menjadi Mie 
Pelaksanaan kegiatan pengabdian ini juga ikut mendampingi tahap produksi dari pengolahan bayam menjadi produk mie yang dapat diolah kembali oleh konsumen. Bayam yang sudah dipanen dipersiapkan sedemikian rupa sehingga siap diolah menjadi berbagai produk makanan turunan dari mie.

\section{KESIMPULAN}

Rangkaian pelaksanaan kegiatan pengabdian yang telah dilaksanakan pada tahun 2020 ini berhasil meningkatkan pemberdayaan perempuan di wilayah Bandar Labuhan melalui komunitas perempuan di wilayah tersebut. Secara bersama-sama anggota komunitas mengelola lahan yang tak terpakai dan menjadikannya produktif secara ekonomi. Hasil panen dapat dijadikan bahan baku produksi mie sehat dan dijual kembali oleh komunitas. Aktivitas ini meningkatkan perekonomian masyarakat. Selain itu, uji coba pembuatan mie sehat berbahan dasar bayam telah sukses dilaksanakan. Produksi ini akan menjadi daya saing tersendiri bagi komunitas UMKM WarnaWarni yang dapat memanfaatkan usaha ini sebagai usaha bersama ataupun mengembangkannya menjadi usaha kuliner berbasis mie sehat tersebut.

\section{UCAPAN TERIMAKASIH}

Penulis mengucapkan terima kasih yang sebesar-besarnya kepada Universitas Sumatera Utara khususnya Lembaga Pengabdian Masyarakat USU yang telah mendanai kegiatan pengabdian ini di bawah skema pengabdian Profesor Mengabdi 2020. Penulis juga mengucapkan terima kasih kepada komunitas UMKM warna-warni serta pemerintah Tanjung Morawa yang mendukung pelaksanaan kegiatan pengabdian ini.

\section{REFERENSI}

Al-Hawary, S. I. S. (2015). Human resource management practices as a success factor of knowledge management implementation at health care sector in Jordan Department of Business Administration. International Journal of Business and Social Science, 6(11), 83-98.

Anton, S. A., Muzakan, I., \& Muhammad, W. F.
(2015).
An
Assessment
of SME
Competitiveness in Indonesia. Journal of
Competitiveness, $\quad 7(2), \quad 60-74$.
https://doi.org/10.7441/joc.2015.02.04

Dervishi, B. (2017). The Problem of Unemployment and a Proposal for a Solution. International Journal of Research in Business and Social Science (2147-4478), 6(1), 21-29. https://doi.org/10.20525/ijrbs.v6i1.673

Gopalakrishnan, D. R. (2019). Advantages and Nutritional Value of Organic Food on Human Health. International Journal of Trend in Scientific Research and Development, Volume3(Issue-4), 242-245. https://doi.org/10.31142/ijtsrd23661

Indonesian Statistics Bureau. (2017). Indonesian Unemployment Rate based on Educationa Level.

Lubis, A. N. (2018). Evaluating the customer preferences of online shopping: Demographic factors and online shop application issue. Academy of Strategic Management Journal, 17(2), 1-13.

Maqbool, S., Rafiq, M., Imran, M., Quadeer, A., \& Abbas, T. (2014). Creating Competitive Advantage Through Supply Chain Management. International Journal of Research in Commerce, IT \& Management, 4(1041). Retrieved from http://ijrcm.org.in/

Ogbechie, R. (2015). An Appraisal of Succession Planning in Family-Owned Businesses in Lagos State , Nigeria, 7(12), 1-6.

Raheja, K. (2015). Methods of Training And Development. Innovative Journal of Business and Management, 35-41.

Rolitia, M., Achdiani, Y., \& Eridiana, W. (2016). Nilai Gotong Royong Untuk Memperkuat Solidaritas Dalam Kehidupan Masyarakat Kampung Naga. Sosietas, 6(1). https://doi.org/10.17509/sosietas.v6i1.2871

Sadiku, M. N. O., Musa, S. M., \& Ashaolu, T. J. (2019). Food Industry: An Introduction. International Journal of Trend in Scientific Research and Development, Volume-3(Issue-

$$
\text { Ekonomi, Sosial, dan Budaya }
$$



4), https://doi.org/10.31142/ijtsrd23638

Siahaan, E. (2015). Concept and Application of Managerial Economics in Business Practices (1st ed.). Medan: USU Press.

Sigurdsson, V., Larsen, N. M., \& Gunnarsson, D. (2014). Healthy food products at the point of purchase: An in-store experimental analysis. Journal of Applied Behavior Analysis, 47(1), 151-154. https://doi.org/10.1002/jaba.91

Soylu, Ö. B., Çakmak, İ., \& Okur, F. (2018). Economic growth and unemployment issue:
Panel data analysis in Eastern European Countries. Journal of International Studies, 11(1), 93-107. https://doi.org/10.14254/20718330.2018/11-1/7

Yusr, M. M., Mokhtar, S. S. M., Salimon, M. G., \& Perumal, S. (2018). The strategic options to enhance the competitive advantage of Malaysian restaurant sector. Geojournal of Tourism and Geosites, 21(1), 123-132. 